\title{
EVALUATION OF PHYSICAL AND CHEMICAL COMPOSITION OF CONCENTRATED FERMENTED CABBAGE JUICE
}

\author{
*Liene Jansone, Solvita Kampuse, Zanda Kruma, Ivo Lidums \\ Latvia University of Life Sciences and Technologies, Latvia \\ *Corresponding author's email: liene.jansone@gmail.com
}

\begin{abstract}
Fermented products have gained worldwide popularity for their nutritional and health aspects. Many studies have been done on this topic, including fermented cabbage (sauerkraut). Yet little or no studies are done on evaluation of fermented cabbage juice which is considered as by-product of sauerkraut production, still rich in bioactive compounds. In order to reduce food waste, sustainable solutions are being searched for to preserve valuable fermented cabbage juice. The aim of this study was to evaluate chemical and physical composition of concentrated fermented cabbage juice and their changes after storage. The fermented cabbage juice was concentrated on falling film evaporator from 9.2 till $34.3^{\circ}$ Brix. Physio-chemical (moisture, $\mathrm{pH}$, total soluble solids, total phenol content, antiradical activity by $\mathrm{DPPH}$ and $\mathrm{ABTS}^{+}$, ascorbic acid, total sugar profile, nitrates and minerals) and microbiological (lactic acid bacteria, total plate count) analyses were carried out. Concentrated fermented cabbage juice is a source of minerals and phenol compounds as well as salt substitute in food applications. After 6 months of storage there is significant degradation of ascorbic acid but total phenol content is not affected. The evaporation process did not inhibit microbiological activity; as a result, there is a decrease in lactic acid bacteria but increase in total plate count.
\end{abstract}

Key words: fermented cabbage juice, concentrate, evaporation, storage, nutritional value.

\section{Introduction}

Fermented cabbage juice is considered as byproduct, yet it is rich in bioactive compounds. There are many studies on fermented cabbage (sauerkraut); however, there are no studies on composition of fermented cabbage juice. Fermented cabbage is rich in vitamin $\mathrm{C}\left(14.7\right.$ - $\left.75 \mathrm{mg} 100 \mathrm{~g}^{-1}\right)$, biogenic amines, organic acids, (Satora et al., 2021a), especially lactic acid, sugars like glycose and fructose, phenolic compounds and glucosinolates, as well as minerals like $\mathrm{Na}$ (661 mg $100 \mathrm{~g}^{-1}$ ), Ca (30 mg $100 \mathrm{~g}^{-1}$ ), K (170 mg $100 \mathrm{~g}^{-1}$ ) (Peñas et al., 2017). Sauerkraut juice contains all the same bioactive compounds. Fermentation process increases vegetable shelf life, nutritional value, sensory quality with unique flavours and textures as well as fermented vegetables promote health of gut microbiome and digestive system, enhancing the immune system (Xiang et al., 2019).

Investigation of the potential use of this valuable product can bring innovative and sustainable solutions in the production process (Beganović et al., 2014).

Generally, juices are concentrated in order to reduce transport, storage and packaging costs (Dincer et al., 2016) as well as prolong shelf life by reducing water activity (Brugnoni et al., 2013). Fruits and vegetables are usually consumed fresh in season, but not all the crop can be utilized that way (Sabanci \& Icier, 2017) so different production techniques are being used dried, frozen, canned and concentrated. Orange, apple and fruit juice mixtures are the most frequent juices concentrated worldwide (Adnan et al., 2018).

One of the techniques applied in concentrating juice is via evaporation - separating water from juice by means of heat energy and pressure. There is a variety of evaporation techniques used - multifactor, kettle, vacuum pan evaporators, as well as rising and falling film evaporators (Adnan et al., 2018). Falling film evaporator was used in our study as it is suitable for heat- sensitive products and has a short residence time and high heat transfer coefficients (Chawankul et al., 2001). The principles of falling film evaporator: the juice or liquid to be concentrated is distributed at the top of heating tubes letting flow down the inside of the tube walls as a thin film. The liquid is partially evaporated due to external heating of the heating tubes. The downward flow, caused initially by gravity, is enhanced by the parallel, downward flow of the vapor formed (Gong et al., 2020).

The more juice is concentrated, the less it resembles original product, even if reconstituted back to original dilution (Adnan et al., 2018) this can be due to vulnerability of volatile, flavouring and sugar compounds on heat processing conditions. However, concentrated juices have higher resistance to microbial (Dutra et al., 2021) activity (Sabanci \& Icier, 2017) and can preserve antioxidant capacity and bioactive compounds as in concentrated grape juice (Deniz Korkmaz, n.d.). Concentrated fermented cabbage juice could be used in food industry like meat, bread, etc. production. Shelf life of concentrated juices vary depending on raw materials and are from one year to three years (Salehi, 2020). The aim of this study was to evaluate chemical and physical properties of concentrated fermented cabbage juice and their changes after storage.

\section{Materials and Methods}

Cabbages of harvest of the 2019 were used for this experiment. Fermented cabbages were obtained using traditional technology applied in LTD Dimdini. Average ratio of cabbages and juice was 3:1. Initial 
soluble solids content of fermented cabbage juice were $9.1^{\circ}$ Brix. Fermented cabbage juice was concentrated using falling film evaporator FF2000 Pilot with the temperatures in calandria being $68^{\circ} \mathrm{C}$ and in separator $62{ }^{\circ} \mathrm{C}$, capacity $1460 \mathrm{~kg} \mathrm{~h}^{-1}$ located at production plant of 'Smiltenes piens' Ltd. The juice was evaporated till $34.3{ }^{\circ}$ Brix which was the maximal evaporation ratio in first stage evaporation. Pilot experiments of concentration were performed on laboratory scale rotary evaporation equipment (Heidolph Laborata 4000 efficient) reaching $30^{\circ} \mathrm{Brix}$, to evaluate stability of compounds. After evaporation process the obtained concentrate was cooled down and filled in $10 \mathrm{~L}$ plastic bags, stored in refrigerator at $4 \pm 2{ }^{\circ} \mathrm{C}$. Totally $2000 \mathrm{~L}$ of concentrate were obtained, for current experiment $30 \mathrm{~L}$ were used and the rest of it was used for new product development. Three replications were carried out throughout the experiment.

Analytical procedures were carried out in Latvia University of Life Sciences and Technologies, Faculty of Food Technology and in collaboration with laboratory group J.S. Hamilton. Physical, chemical and microbiological parameters were tested in two periods of time - right after the evaporation process and after 6 months of storage in the refrigerator.

Physico-chemical parameters

$\mathrm{pH}$ was measured with $\mathrm{pH}$-meter Jenway 3510 (Baroworld Scientific Ltd., UK) applying standard method LVS ISO 5542:2010. Soluble solids content ( ${ }^{\circ}$ Brix) was measured using digital refractometer Refracto 30GS (Mettler Toledo, Japan) as described in standard method ISO 2173:2003. For moisture content samples were dried at $105 \pm 1{ }^{\circ} \mathrm{C}$ (Universal Oven UF55, Memmert, Germany) till constant weight, according to standard ISO 6496:1999. Salt content was determined by titration as described in Mohr's method, according to standard IDF 12|ISO 1738:2004. Silver nitrate solution and potassium chromate indicator were used (Deniz Korkmaz, n.d.). Nutritional composition

Protein $\left(\mathrm{N}^{*} 6.25\right)$ amount was determined according to method PB-116 ed. II of 30.06.2014. Dietary fibber was determined according to AOAC 991.43:1994. Ash content was determined according to PN-A-75101-08:1990+Az 1:2002. Minerals were determined according to method PB-223/ICP, ED II of 12.01.2015. Fat content was determined according to PB-286 ed. I of 26.09.2014. For sugar profile enzymatic - spectrophotometric method was used Carbohydrates were calculated as dietary fibre and total sugar content. Energy value was determined according to Regulation (EU) No 1169/2011 of the European Parliament and of the Council of 25 October 2011. Nitrates were determined according to method PN-A-75112:1992. Analytical procedures were done by laboratory group J.S. Hamilton.

\section{Bioactive compounds and antioxidant activity}

For total phenol content and antiradical activity, extracts of $10 \mathrm{~mL}$ of the sample and $20 \mathrm{~mL}$ ethanol (80:20 v/v) were made and stirred for $2 \mathrm{hrs}$, then filtered. The total phenol content was determined by Folin - Ciocalteu method as described by Singleton et al. (Singleton et al., 1999) with some modifications, as described previously (Jansone \& Kampuse, 2019) Absorption was read at $765 \mathrm{~nm}$ on a spectrophotometer Jenway 6300 (Baroworld Scientific Ltd., UK). For antiradical scavenging activity by DPPH, 3,5 mL freshly made DPPH stock solution (0.004 g of 2.2-diphenil-1-picrylhydrazyl was mixed with $96 \%$ ethanol to reach the absorption of $1.000 \pm 0.02$ at $517 \mathrm{~nm}$ ) were added to $0.5 \mathrm{~mL}$ sample extract and left to react in the dark place for $30 \mathrm{~min}$, as described by K. Thaipong (Thaipong et al., 2006). The analyses were done in three replications and the results were determined spectrophotometrically. For antiradical decolouration method by $\mathrm{ABTS}^{+}$, stock solution was made with 2.2-azinobis-(3-ethylbenztiazoline-6-sulphonic aid), phosphate buffered saline and potassium per sulphate as the oxidant and left to react for $16 \mathrm{~h}$ in the dark (to reach the absorption of $0.800 \pm 0.030$ at $734 \mathrm{~nm}) .5 \mathrm{~mL}$ of stock were added to $0.05 \mathrm{~mL}$ sample extracts, left to react for $10 \mathrm{~min}$. The analyses were done in three replications and the results were determined spectrophotometrically, as described by S. Rokayya (Rokayya et al., 2013) with some modifications. Ascorbic acid content was determined by titration after iodine method T-138-15-01:2002 which defines L-ascorbic acid that is reduced form of ascorbic acid, described by D.Seglina (Seglina, 2007). Microbiological parameters

Microbiological parameters - $10 \mathrm{~mL}$ of the fermented cabbage juice concentrate were diluted in $90 \mathrm{~mL}$ sterile saline $(0.9 \% \mathrm{NaCl})$ in an internal filter bag and mixed in a stomacher (Bagmixer Interscience, Bois Arpents F.) for $1 \mathrm{~min}$. A $1 \mathrm{~mL}$ and $0.1 \mathrm{~mL}$ of filtrate were cultured on MRS agar (Scharlau, ref. nr. 01-135-500) for lactic acid bacteria, according to standard LVS ISO 15214:1998 and on PCA (Plate Count Agar) agar (Scharlau, ref.nr. 01-161-500) for total plate count, according to standard LVS EN ISO 4833-1:2013. The samples were incubated as follows: MRS $37{ }^{\circ} \mathrm{C} 72 \mathrm{~h}$ and PCA $30^{\circ} \mathrm{C} 48 \mathrm{~h}$. Enumeration was carried out on Acolyte colony counter.

Statistical data analyses

T-test, arithmetic mean and standard deviation was used on programme Excel (Microsoft) to determine statistical differences.

\section{Results and Discussions}

Chemical composition of the cabbage, sequentially fermented cabbage and its products, like dehydrated or concentrated fermented cabbage juice, are strongly 
influenced by many factors - meteorological and soil conditions (Satora et al., 2021b), storage and temperature, production process (Yang et al., 2020) variety and other effects (Burdurlu et al., 2006).

Nutritional value of concentrated fermented cabbage juice is summarized in Table 1.

\section{Nutritional value of concentrated fermented} cabbage juice

\begin{tabular}{|l|c|c|}
\hline \multicolumn{1}{|c|}{ Parameters } & Unit & Content per $100 \mathrm{~g}$ \\
\hline Energy value & $\mathrm{kJ}$ & 320 \\
\hline Carbohydrates & $\mathrm{g}$ & 13.0 \\
\hline - including sugars & $\mathrm{g}$ & 7.5 \\
\hline \multicolumn{1}{|c|}{ Glucose } & $\mathrm{g}$ & 5.5 \\
\hline \multicolumn{1}{|c|}{ Fructose } & $\mathrm{g}$ & 1.5 \\
\hline \multicolumn{1}{|c|}{ Maltose } & $\mathrm{g}$ & 0.2 \\
\hline \multicolumn{1}{|c|}{ Galactose } & $\mathrm{g}$ & 0.3 \\
\hline - dietary fibre & $\mathrm{g}$ & 1.1 \\
\hline Protein & $\mathrm{g}$ & 5.3 \\
\hline Fat & $\mathrm{g}$ & $<0.1$ \\
\hline Ash & $\mathrm{g}$ & 9.42 \\
\hline Salt & $\mathrm{g}$ & 6.33 \\
\hline
\end{tabular}

Energy value of concentrated fermented cabbage juice was $320 \mathrm{~kJ} 100 \mathrm{~g}^{-1}$. Carbohydrates including

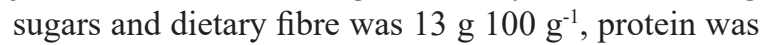

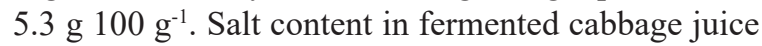

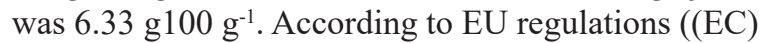
No 1924/2006), it is considered as high and thus can be used in food formulations substituting salt.

The sugar content in concentrated fermented cabbage juice was $7.5 \mathrm{~g}$, with glucose being $5.5 \mathrm{~g}$ as dominated monosaccharide. As it is mentioned by other authors, the concentration of total sugars in sauerkraut samples varies from 0.3 to $1.7 \%$ wet weight, glucose being $<1$ (Hughes \& Lindsay, 1985). The sugar (glucose, fructose, sucrose) content varies in fermented cabbage and its juice due to metabolic and microbiological activity (Xiong et al., 2016).

The ash content in concentrated fermented cabbage juice is $9.42 \mathrm{~g}$, thus it contains a variety of minerals like $\mathrm{Mg}, \mathrm{Cu}, \mathrm{K} \mathrm{Ca}, \mathrm{Fe}$ as shown in Table 2 . In comparison, fresh cabbage contains $200-300 \mathrm{mg}$ $100 \mathrm{~g}^{-1}$ and fermented cabbage - $700-800 \mathrm{mg} 100 \mathrm{~g}^{-1}$ minerals (Khanna, 2018). The fermentation process may increase the mineral content of the cabbage (Ifesan et al., 2014). The role of minerals in human nutrition and metabolism is essential (Mensink et al., 2013), but amount of potassium in this concentrate is noticeable. It is the main cation in intracellular fluid and ensures cell function (Healthcare Research, n.d.). Potassium interacts in regulating blood pressure, reduction of kidney stones and cardiovascular diseases (Hmelak, Gorenjak, \& Cencič, 2013; Sākumlapa Slimību Profilakses un Kontroles Centrs, n.d.)

Brassicaceae (rocket, mustard as well as cabbage) vegetables are considered as nitrate accumulating sources like many green leafy vegetables, and there is a large variation in concentration what is influenced by many factors. The nitrate concentration in leafy vegetables is regulated by European Commission (Commission, 2010)) and the nitrate content is considered as very low if it is below $200 \mathrm{mg}$ $100 \mathrm{~g}^{-1}$ fresh weight (Hmelak, Gorenjak, \& Cencič, 2013; Sākumlapa | Slimību Profilakses un Kontroles Centrs, n.d.). The nitrate content in concentrated fermented cabbage juice is considered as low with no harmful impact on health, according to WHO (World Health Organisation).

Table 2

\section{Mineral and nitrate content in concentrated fermented cabbage juice and acceptable daily intake}

\begin{tabular}{|l|c|c|}
\hline \multicolumn{1}{|c|}{ Parameter } & Results & RDI* \\
\hline Minerals & $\mathbf{m g ~} \mathbf{1 0 0} \mathbf{~ g}^{\mathbf{- 1}}$ & $\mathbf{m g} / \mathbf{d a y}$ \\
\hline Magnesium & 67.8 & 280 \\
\hline Copper & 0.11 & 0.9 \\
\hline Potassium & 1358 & 3100 \\
\hline Calcium & 238 & 800 \\
\hline Iron & 1.14 & 15 \\
\hline Nitrates & & \\
\hline Nitrates as $\mathrm{NaNO}_{3}$ & 151 & 222 \\
\hline Nitrates as $\mathrm{NO}_{3}{ }^{-}$ & 110 & 222 \\
\hline
\end{tabular}

* Recommended daily intake. These recommendations are for female 18 - 60 years old. The RDI for nitrates is for grown-up, $60 \mathrm{~kg}$ body weight (Piljac-Žegarac et al., 2009; Slimību Profilakses un Kontroles Centrs, n.d.)

Physicochemical and microbiological parameters are summarized in Table 3.

- values marked with different letters in the same row differ significantly at the level of significance $\mathrm{p}<0.005$.

$\mathrm{pH}$ of the concentrated fermented cabbage juice was from $3.92 \pm 0.06$ at the beginning of this experiment to $3.86 \pm 0.04$ after 6 months. The initial $\mathrm{pH}$ of fermented cabbage juice usually is $3.4-$ 3.8. Total soluble solids of concentrated fermented cabbage juice was $34.33 \pm 0.02{ }^{\circ}$ Brix, after 6 months of storage the soluble solids slightly increased to $34.74 \pm 0.02{ }^{\circ}$ Brix which could be explained by vague evaporation. Due to our previous experiments, not described in this article, total soluble solids of $34-$ $35^{\circ}$ Brix was optimum for first stage evaporation. 


\section{Physicochemical and microbiological parameters of concentrated fermented cabbage juice before and after storage}

\begin{tabular}{|c|c|c|}
\hline \multirow{2}{*}{ Parameters } & \multicolumn{2}{|c|}{ Concentrated juice } \\
\hline & Before storage & After storage \\
\hline pH & $3.92 \pm 0.06 \mathrm{a}^{*}$ & $3.86 \pm 0.04 \mathrm{~b}$ \\
\hline Soluble solids, ${ }^{\circ}$ Brix & $34.33 \pm 0.02 b$ & $34.74 \pm 0.02 \mathrm{a}$ \\
\hline Moisture, \% & $70.29 \pm 0.19 a$ & $69.44 \pm 0.11 b$ \\
\hline Total phenols, mg GAE $100 \mathrm{~g}^{-1}$ & $530.06 \pm 12.72 \mathrm{a}$ & $521.19 \pm 10.29 \mathrm{a}$ \\
\hline DPPH, mg TE $100 \mathrm{~g}^{-1}$ & $822.17 \pm 12.02 \mathrm{a}$ & $350.23 \pm 5.24 b$ \\
\hline ABTS, mg TE $100 \mathrm{~g}^{-1}$ & $23.70 \pm 1.74 \mathrm{a}$ & $20.40 \pm 3.23 b$ \\
\hline Ascorbic acid, mg $100 \mathrm{~g}^{-1}$ & $110.00 \pm 4.34 \mathrm{a}$ & $26.66 \pm 2.47 \mathrm{~b}$ \\
\hline Lactic acid bacteria, CFU g ${ }^{-1}$ & $4.6 \times 10^{4} \mathrm{a}$ & $1.2 \times 10^{4} \mathrm{~b}$ \\
\hline Total plate count, $\mathrm{CFU} \mathrm{g}^{-1}$ & $3.8 \times 10^{4} \mathrm{a}$ & $1.6 \times 10^{5} \mathrm{~b}$ \\
\hline
\end{tabular}

Ascorbic acid content. There was considerable decrease in ascorbic acid content in the concentrate during storage from 110 to $26.6 \mathrm{mg} 100 \mathrm{~g}^{-1}$, and as it can be seen from our experiment, even storage at $4 \pm$ $2{ }^{\circ} \mathrm{C}$ temperature is not sufficient for stabilization of ascorbic acid degradation. As it is mentioned by other authors, ascorbic acid (AA) degradation (usually anaerobic during storage) is influenced by many storage factors like storage time, light and others (Piljac-Žegarac et al., 2009).

Total phenol content (TPC) in concentrated fermented cabbage juice was $530.06 \pm 12.72$ and $521.19 \pm 10.29 \mathrm{mg}$ GAE $100 \mathrm{~g}^{-1}$ after 6 months of storage. Like the stability of AA is influenced by many factors, so is the stability of dark fruit juice polyphenols (Dianawati et al., 2016). The scientists also studied the fluctuations in the total phenol content during storage in the dark fruit juice concentrates. There is a decrease of TPC observed from 2 weeks to 6 months of storage at $\pm 4{ }^{\circ} \mathrm{C}$ after which, however total phenol content increases again. The storage time and fluctuations of the TPC are individual for different fruit or berry juices. "It is possible that during juice storage, some compounds are formed that react with the Folin-Ciocalteu reagent and significantly enhance the phenolic content" (Yang et al., 2020). There are several findings that suggest that phenolic compounds remain stable and do not lower the concentration during storage (Yang et al., 2020).

Antiradical activity by DPPH was $822.2 \pm 12.02$ after evaporation process, and it dropped to $350.2 \pm$ $5.24 \mathrm{mg}$ TE $100 \mathrm{~g}^{-1}$ after storage. There were fluctuations observed during storage in antiradical activity by DPPH in oranges (Arena et al., 2001). The antiradical activity in black mulberry juice concentrate also decreased during storage and was influenced by many factors, like storage time, temperature and composition of the product (Dincer et al., 2016). The loss of ascorbic acid may have a contribution to decrease of antiradical activity (Yang et al., 2020). Antiradical activity by ABTS results were $23.7 \pm 1.74$ at the beginning of the experiment and $20.400 \pm 3.23$ mg TE $100 \mathrm{~g}^{-1}$ after storage.

\section{Microbiological Parameters}

The viability of microorganisms is influenced by many factors (Yang et al., 2020) as well as their activity. Fermented cabbage and its juice are considered a valuable source of lactic acid bacteria (LAB) (Yang et al., 2020), so in our study we were paying closer look at LAB survival during concentration process and storage impact. The LAB count after evaporation process was $4.6 \times 10^{4} \mathrm{CFU} \mathrm{g}^{-1}$ but it decreased after 6 months of storage and was $1.2 \times 10^{4} \mathrm{CFU} \mathrm{g}^{-1}$. Total plate count, acted quite the opposite being $3.8 \times 10^{4}$ CFU g ${ }^{-1}$ after evaporation and $1.6 \times 10^{5} \mathrm{CFU} \mathrm{g}^{-1}$ after storage period.

\section{Conclusions}

Concentrated cabbage juice with soluble solids content $30^{\circ}$ Brix contained carbohydrates as the main nutrient, followed by high ash content, including various minerals most abundant being potassium $1174 \mathrm{mg} 100 \mathrm{~mL}^{-1}$. The nitrate content in concentrated fermented cabbage juice is recognized as low $(<200 \mathrm{mg}$ $\left.100 \mathrm{~g}^{-1}\right)$. After the storage of concentrated fermented cabbage juice for six months at $4{ }^{\circ} \mathrm{C}$ temperature, total phenol content decreased from 530.06 to $521.19 \mathrm{mg}$ GAE $100 \mathrm{~g}^{-1}$, whereas antiradical activity (by DPPH) and ascorbic acid content decreased significantly from 822.17 to $350.23 \mathrm{mg}$ TE $100 \mathrm{~g}^{-1}$ and 110.0 to 26.66 mg $100 \mathrm{~g}^{-1}$ accordingly. LAB count decreased during storage from $4.6 \times 10^{4} \mathrm{CFU} \mathrm{g}^{-1}$ to $1.2 \times 10^{4} \mathrm{CFU} \mathrm{g}^{-1}$ whereas total microorganism activity increased 
$3.8 \times 10^{4} \mathrm{CFU} \mathrm{g}{ }^{-1}$ to $1.6 \times 10^{5} \mathrm{CFU} \mathrm{g}^{-1}$. Concentrated fermented cabbage juice is a source of minerals and polyphenol compounds as well as due to a high salt content $(6.33 \%)$ could be applied as salt substitute in food applications.

\section{Acknowledgements}

This study was supported by European Innovation Partnership for Agricultural Productivity and Sustainability Working Group Cooperation project 18-00-A01612-000020.

\section{References}

Adnan, A., Mushtaq, M., \& Islam, T. (2018). Fruit Juice Concentrates. In Fruit Juices: Extraction, Composition, Quality and Analysis. Elsevier Inc. DOI: 10.1016/B978-0-12-802230-6.00012-6.

Arena, E., Fallico, B., \& Maccarone, E. (2001). Evaluation of antioxidant capacity of blood orange juices as influenced by constituents, concentration process and storage. Food Chemistry, 74(4), 423-427. DOI: 10.1016/S0308-8146(01)00125-X.

Brugnoni, L.I., Pezzutti, A., \& Gonzalez, M.T. (2013). Effect of storage conditions on microbiological and physicochemical parameters of cloudy apple juice concentrate. International Journal of Food Engineering, 9(1), 67-74. DOI: 10.1515/ijfe-2012-0156.

Burdurlu, H.S., Koca, N., \& Karadeniz, F. (2006). Degradation of vitamin C in citrus juice concentrates during storage. Journal of Food Engineering, 74(2), 211-216. DOI: 10.1016/j.jfoodeng.2005.03.026.

Chawankul, N., Chuaprasert, S., Douglas, P., \& Luewisutthichat, W. (2001). Simulation of an agitated thin film evaporator for concentrating orange juice using AspenPlusTM. Journal of Food Engineering, 47(4), 247-253. DOI: 10.1016/S0260-8774(00)00122-9.

Deniz Korkmaz, by. (n.d.). Precipitation Titration: Determination of Chloride by the Mohr Method.

Dianawati, D., Mishra, V., \& Shah, N.P. (2016). Survival of Microencapsulated Probiotic Bacteria after Processing and during Storage: A Review. Critical Reviews in Food Science and Nutrition, 56(10), 16851716. DOI: 10.1080/10408398.2013.798779.

Dincer, C., Tontul, I., \& Topuz, A. (2016). A comparative study of black mulberry juice concentrates by thermal evaporation and osmotic distillation as influenced by storage. Innovative Food Science and Emerging Technologies, 38, 57-64. DOI: 10.1016/j.ifset.2016.09.012.

Dutra, M. da C.P., Viana,A.C., Pereira, G.E., Nassur, R. de C.M.R., \& Lima, M. dos S. (2021). Whole, concentrated and reconstituted grape juice: Impact of processes on phenolic composition, "foxy" aromas, organic acids, sugars and antioxidant capacity. Food Chemistry, 343, 128399. DOI: 10.1016/j.foodchem.2020.128399.

Healthcare Research, A. (n.d.). Comparative Effectiveness Review Number 206 Sodium and Potassium Intake: Effects on Chronic Disease Outcomes and Risks e. Retrieved March 6, 2021, from www.ahrq.gov.

Gong, L., Zhou, S., Guo, Y., \& Shen, S. (2020). Distribution of brine temperature in a large-scale horizontaltube falling film evaporator. In Applied Thermal Engineering (Vol. 164, p. 114437). Elsevier Ltd. DOI: 10.1016/j.applthermaleng.2019.114437.

Hmelak Gorenjak, A., \& Cencič, A. (2013). Nitrate in vegetables and their impact on human health. A review. Acta Alimentaria, 42(2), 158-172. DOI: 10.1556/AAlim.42.2013.2.4.

Ifesan, B.O.T., Egbewole, O.O., \& Ifesan, B.T. (2014). Effect of Fermentation on Nutritional Composition of Selected Commonly Consumed Green Leafy Vegetables in Nigeria. International Journal of Applied Sciences and Biotechnology, 2(3), 291-297. DOI: 10.3126/ijasbt.v2i3.11003.

Jansone, L., \& Kampuse, S. (2019). Comparison of chemical composition of fresh and fermented cabbage juice. DOI: 10.22616/FoodBalt.2019.028.

Kevers, C., Falkowski, M., Tabart, J., Defraigne, J.O., Dommes, J., \& Pincemail, J. (2007). Evolution of antioxidant capacity during storage of selected fruits and vegetables. Journal of Agricultural and Food Chemistry, 55(21), 8596-8603. DOI: 10.1021/jf071736j.

Khanna, S. (2018).DigitalCommons@UMaine Effects of Salt Concentration on the Physicochemical Properties and Microbial Safety of Spontaneously Fermented Cabbage. Retrieved January 30, 2021, from https:// digitalcommons.library.umaine.edu/etd/3013.

Mensink, G.B.M., Fletcher, R., Gurinovic, M., Huybrechts, I., Lafay, L., Serra-Majem, L., Szponar, L., Tetens, I., Verkaik-Kloosterman, J., Baka, A., \& Stephen, A.M. (2013). Mapping low intake of micronutrients across Europe. British Journal of Nutrition, 110(4), 755-773. DOI: 10.1017/S000711451200565X.

Nindo, C.I., Powers, J.R., \& Tang, J. (2007). Influence of Refractance Window evaporation on quality of juices from small fruits. LWT - Food Science and Technology, 40(6), 1000-1007. DOI: 10.1016/j.lwt.2006.07.006.

Piljac-Žegarac, J., Valek, L., Martinez, S., \& Belščak, A. (2009). Fluctuations in the phenolic content and antioxidant capacity of dark fruit juices in refrigerated storage. Food Chemistry, 113(2), 394-400. DOI: 10.1016/j.foodchem.2008.07.048. 
Rokayya, S., Li, C.J., Zhao, Y., Li, Y., \& Sun, C.H. (2013). Cabbage (Brassica oleracea L. var. capitata) phytochemicals with antioxidant and anti-inflammatory potential. Asian Pacific Journal of Cancer Prevention, 14(11), 6657-6662. DOI: 10.7314/APJCP.2013.14.11.6657.

Sabanci, S., \& Icier, F. (2017). Applicability of ohmic heating assisted vacuum evaporation for concentration of sour cherry juice. Journal of Food Engineering, 212, 262-270. DOI: 10.1016/j.jfoodeng.2017.06.004.

Slimību profilakses un kontroles centrs, Center of Desease Prevention and Control. Retrieved March 6, 2021, from https://www.spkc.gov.lv/lv.

Seglina, D. (2007). Sea buckthorn fruits and their processing products. Summary of promotion work for acquiring the Doctor's degree of Engineering Sciences in the Food Science. (s.n.). Retrieved February 13, 2021, from https://agris.fao.org/agris-search/search.do?recordID=LV2007000578.

Singleton, V.L., Orthofer, R., \& Lamuela-Raventós, R.M. (1999). Analysis of total phenols and other oxidation substrates and antioxidants by means of folin-ciocalteu reagent. Methods in Enzymology, 299, 152-178. DOI: 10.1016/S0076-6879(99)99017-1.

Stone, M.S., Martyn, L., \& Weaver, C.M. (2016). Potassium intake, bioavailability, hypertension, and glucose control. In Nutrients (Vol. 8, Issue 7). MDPI AG. DOI: 10.3390/nu8070444.

Thaipong, K., Boonprakob, U., Crosby, K., Cisneros-Zevallos, L., \& Hawkins Byrne, D. (2006). Comparison of ABTS, DPPH, FRAP, and ORAC assays for estimating antioxidant activity from guava fruit extracts. Journal of Food Composition and Analysis, 19(6-7), 669-675. DOI: 10.1016/j.jfca.2006.01.003.

Xiong, T., Li, J., Liang, F., Wang, Y., Guan, Q., \& Xie, M. (2016). Effects of salt concentration on Chinese sauerkraut fermentation. LWT - Food Science and Technology, 69, 169-174. DOI: 10.1016/j.lwt.2015.12.057.

Yang, X., Hu, W., Xiu, Z., Jiang, A., Yang, X., Ji, Y., Guan, Y., \& Feng, K. (2020). Comparison of northeast sauerkraut fermentation between single lactic acid bacteria strains and traditional fermentation. DOI: 10.1016/j.foodres.2020.109553. 